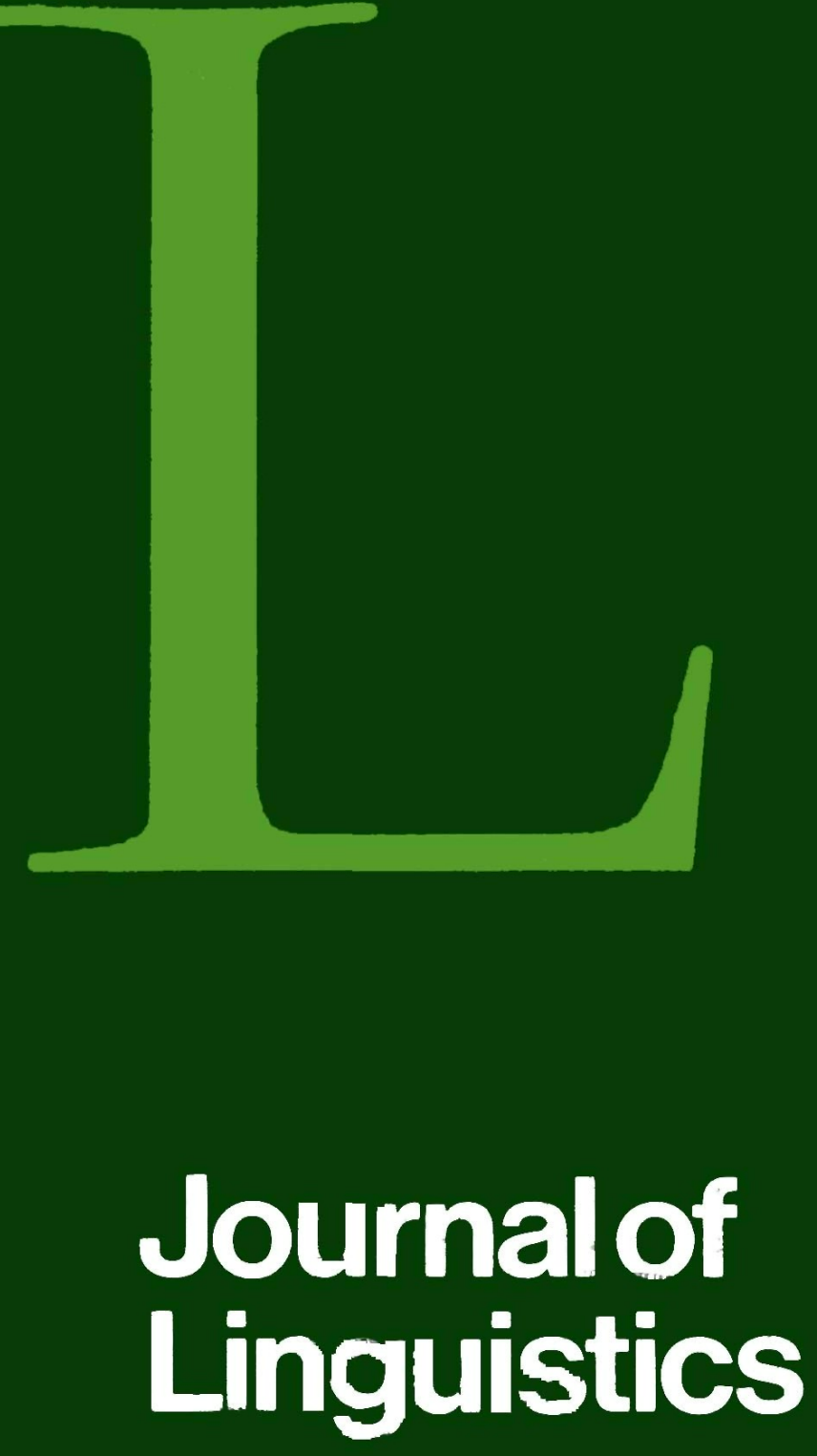

Published for the

Linguistics Association of Great Britain by

Cambridge University Press 


\title{
JOURNAL OF LINGUISTICS
}

\author{
Editor: Nigel Vincent (University of Manchester) \\ Editorial Bard
}

R. Borsley (UCNW, E. K. Brown (Estex), B. Comrie (S. California), A. Cutfez (Cambridge), N. Burton-Roberts (Newcatle), R. Coates (Susex), R. Kempson (SOAS), D. R. Ladd (Sdinburgh), 5. C. Levirson (Nijmegen), R. Manzini (UCL), L. Milroy (Newcastle), I, Roberts (UCWW).

\section{Notes for Contribatows and subacribers}

Paticy. The Yournal of Limenistios is concerned with all branches of linguistic (including phonetics). Preference is given to articles of general theoretical interest. Contributions are welcomed from linguiats in ell countries, and not merely from members of the Leinguistics Association of Great Britain. The norpasl language of publication is English.

Fiditomial Address. Nigel Vincent, Depertment of Linguiatics, University of Manchester, Manchester Mx3 9R2, England.

Books for teview should be aent to the Editor.

\section{C) Cambridge Univeraity Press, Igga}

Subseriptions. One volume of the Yournal is published each year in two parts. The subscription price which includes postage is 646 ; USA and Canada US \$85.\% for institutions; 56 for individuals ardering direst from the publisher and certifying that the journal is for their personal we. Single parts are also avajlable ot $f_{3} .00$ net each, USS 45.00 , plus postageOrders, which inust be accompanied by payment, may be placed with any booksellex or subscription agent, or sent ditect to Carribridge University Press, Edinburgh Building, Shaftesbury Road, Cambridge CBa aRU, or, in USA and Canada, Cambridge Univergity Press, Journals Deparmaent, 40 Weat zoth Street, New York, NY roor $x-42 x x$. POSTMASTER: send address changes in the USA and Carrada to Foumal of Lingutrtics, Cambridge Univeraity Prese, $x \times$ Midland Avenue, Port Chester, New York NY xo573-9864.

Claums for the repiacement of jourmals believed to be lost in trensit will only be entertained if made immediately after receipt of the subsequext issues of the Journal.

Coppling This journal is regigtered with the Copyright Clearance Center, 27 Congress Street, Salern, Mass org7s. Organizations im the ISSA who are siso regristered with the C.C.C. rnay therefore copy material (beyond the limita permitted by sections 107 and 108 of USA copyright law) subjest to payment to the C.C.C. of the per-copy fee of \$05.00. This consent does not extend to multiple copying for prometionsl or commercial purposes. Code $0022-2267 / 92 / 01$ $55.00+.00$.

ISI Teax Shet Service, 35o 1 Market Sereet, Philadelphia, Penusylvania Igro4, USA, is authorized to supply single copies of separate articles for privgte use only.

For all other use, persnission should be sought from Carribridge or the American Branch of Cumbridge University Press.

Style, Intending contributors should ensure that their manuscripts conform to the standards lait down in the LSA Style Sheet fprinted periodically in the LSSA Bulletirt), except in the following respects:

(a) Footnotes ahould as fat as possible be avoided; they should not contain wpecial symabols such as those used in the Intermational Phonetic Alphabet.

(b) Phonetic transcriptions should, wherevex possible, make use of the symbols and conventions of the International Phonetic Alphabet, and shoult be no "narrower" than ia abolutely necessary for the purpost.

(c) Bibliographicat references at the end of each articie or review should conform to the following models (trities of periaticals should be abbreviated as in Bibliogratisie lingristique):

Bloomfield, L. (1933). Langreage- New York: Holt.

Bolinger, D. (ro6s). The atomization of raeaning. Lo 42. 555-573.

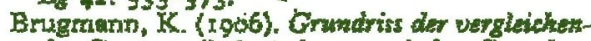
des Crammath der indogermanischew Sprachen. and ed., vol. 2, part x. Strassburg: Trübner. Chafe, W. L. (1965). Review of Longacre, R. E. Grammer discovery pracedares. L8 4x. 640647.

Chomsky, N. (1957). Systactic structures. Uanus. Linguarum, 4.) The Hague: Mouton.

Hockett, C. F. (Ig64). The Proto Central Aigonguiar kinahip aystern. In Goodenowgh,

W. (ed.) Exploranions in cuitural anthropology.

New York: McGrew-Hill. 239-258.

The following requirements of the LSA Style Sheet which will apply to manusacripts intended. for publication in the Yourmal of Linewitices should be particularly noted:

x. All copy must be double-garaced throughoxit, and margins of at least is inches should be left on all four aides of each sheet (LSA style aheet, sections $x(c)$ and $(d)$ ).

3. Tables, charts and diagrams (though not simple rules, examples or formulae) must exch appear on a separate sbeet, and must be labelled "Fig. 2 " "Table 4" or the like as mpropriate. References in the text to the table of dingrars muat be made by citing this label, and not in such terms as "in the diagtam following (LSA style shet, sections $x(e)$ and $x(c))$.

3. Typescripts of atticles thould be subrainted in three copies, typescripte of reviews in two copies. Typescripts will nat be returned uniles: postage is provided by contributors (LSA atyle sheet, section $I(g))$.

4 No part of title or section heading ehould be underscored: the Editors exercies the final choice of type faces in these cases (LSA atyle sheet, section $8(a)$ ).

5. The typescript of an article should be - accomparied by an abetract of about yoo warda summerizing the conceptsial conterst of the article; it should be typed (doublemepend) on separate sheet of paper (LBA atyle aheet, section x.x).

Froots. Firat proofs ondy will be sent to the wuthor (or his nominee), who will be expected to correct them and return them to the Fditor, by airmail where appropriate, within three deye of receipt. 